\title{
Małoletnie macierzyństwo w kontekście polityki rodzinnej
}

W optyce niniejszego artykułu znajduje się macierzyństwo kobiet, które ze względu na swój wiek są społecznie uznawane za zbyt młode, aby zostać matkami. Macierzyństwo to podejmowane jest przez kobiety niepełnoletnie, czyli te, które urodziły dziecko przed ukończeniem osiemnastego roku życia i które nie uzyskały pełnoletniości poprzez zawarcie małżeństwa za zgodą sądu po ukończeniu szesnastu lat ${ }^{1}$. W świetle prawa polskiego osoby te określane są jako małoletnie, co jest równoznaczne z posiadaniem w prawie statusu dziecka ${ }^{2}$. Opisywane zjawisko małoletniego macierzyństwa w kontekście polityki rodzinnej ma na celu przyjrzenie się temu, w jakim zakresie państwo polskie troszczy się o dobrostan rodziny małoletniej matki i jej dziecka. Problematyka ta wiąże się ze współczesną dzieciocentryczną polityką społeczną, która została zapoczątkowana na przełomie XX i XXI wieku. Według Wielisławy Warzywody-Kruszyńskiej polityka ta jest konsekwencją przemian deindustrializacji, globalizacji i przemian demograficz-

$1 \quad$ Art. 10 i 11. ustawy z dn. 23 kwietnia 1964 r. Kodeks cywilny, tekst jedn. Dz.U. 2017, poz. 459 .

2 Ustawa z dn. 6 stycznia 2000 r. o Rzeczniku Praw Dziecka, tekst jedn. Dz.U. Nr 6, poz. 69. 
nych $^{3}$. Ukierunkowanie polityki na wspieranie rozwoju dzieci jako tej grupy, która stanowiła najkorzystniejszą „inwestycję” dającą szansę na wzrost kapitału ludzkiego, zwróciło uwagę społeczną także na kwestię małoletnich matek oraz ich dzieci w społeczeństwie polskim. Jako znaczące w kształtowaniu się fenomenu małoletniego macierzyństwa należy uznać także społeczne zmiany w postrzeganiu instytucji macierzyństwa. Przemiana, która nastąpiła na początku XXI wieku, według Élisabeth Badinter ma „ogromne znaczenie, dotyczy bowiem - ni mniej, ni więcej - ponownego umiejscowienia macierzyństwa w samym centrum losu kobiety" ". Konsekwencją tego są nowe wzory ról macierzyńskich ${ }^{5}$, wśród których małoletnie macierzyństwo staje się jednym z wielu rodzajów macierzyństwa.

\section{Polityka rodzinna a problem społeczny „małoletnich matek”}

Małoletnie macierzyństwo w literaturze przedmiotu jest sytuacją definiowaną w kategorii problemów dotyczących wielu płaszczyzn - indywidualnej ${ }^{6}$, psychospołecznej $^{7}$, medycznej ${ }^{8}$ oraz istotnej dla poruszonej problematyki płaszczyzny społecznej ${ }^{9}$. Zdefiniowanie danego zjawiska jako problemu spo-

3 Zob. szerzej W. Warzywoda-Kruszyńska, Dzieciocentryczna polityka społeczna w założeniach i praktyce, w: O racjonalna politykę rodzinną. Rodzina formacją niezastąpioną?, red. M. Bednarski, Z. Czepulis-Rutkowska, D. Głogosz, Warszawa 2017, s. 45-54.

4 E. Badinter, Konflikt: kobieta i matka, przeł. J. Jedliński, Warszawa 2013, s. 6.

5 M. Sikorska opisuje nowe społeczne wzorce roli matki powstające w opozycji do wzoru tzw. matki Polki - związanego z naturalnym instynktem macierzyństwa: „nowa matka" ma do wyboru wiele wzorców macierzyństwa, stają się one częścią tworzonej przez nią samą autobiografii. Jak zauważa autorka, wzór „,nowej matki” dotyczy kobiet wykształconych ze środowisk wielkomiejskich. Nowe zjawisko ukazuje znaczenie stratyfikacji społecznej w pełnieniu roli matki. Zob. szerzej M. Sikorska, Matka "chora” zamiast „zkej” - o nowych wzorach macierzyństwa, w: Być rodzicem we wspótczesnej Polsce. Nowe wzory w konfrontacji z rzeczywistością, red. M. Sikorska, Warszawa 2009, s. 13-33.

6 E. Włodarczyk, Nastoletnie macierzyństwo jako problem indywidualny i społeczny, w: Kapitał społeczny a nierówności - kumulacja i redystrybucja, red. K. Marzec-Holka, Bydgoszcz 2009, s. 454-463.

7 G. Mikołajczyk-Lerman, Małoletnie rodzicielstwo jako problem psychospołeczny, „Polityka Społeczna” 8 (2007), s. 54-59.

8 O. Padała i in., Młodociane macierzyństwo jako problem społeczny i medyczny, „European Journal of Medical Technologies" 2 (2014) nr 3, s. 61-65.

9 P. Bunio-Mroczek, Wczesne rodzicielstwo - zagrożenie czy szansa? Nastoletni rodzice z łódzkich enklaw biedy, Łódź 2016; P. Bunio-Mroczek, W. Warzywoda-Kruszyńska, Wczesne 
łecznego pozwala na wysunięcie roszczenia wobec państwa o rozwiązanie problemu. Proces ujawniania się danej sytuacji jako problemu społecznego przebiega według określonej trajektorii. Koncentracja społeczeństwa na danej kwestii społecznej przebiega według pięciu faz, które wskazał w latach 70. XX wieku Anthony Downs. W określonym czasie problem nagle staje się coraz ważniejszy społecznie, pozostaje w uwadze opinii publicznej, czasem przez krótki czas, by stopniowo - pozostając nawet w znacznym stopniu nierozwiązanym - zniknąć z centrum uwagi publicznej. W pierwszym etapie, określanym jako przedproblemowym (pre-problem stage), w społeczeństwie pojawia się niepożądana sytuacja, która znajduje się jeszcze poza zainteresowaniem opinii publicznej. Istotne jest to, że obiektywnie sytuacja ta jest gorsza na etapie poprzedzającym uznanie jej za problem. Kolejny, drugi etap wywoływany jest najczęściej dramatycznym wydarzeniem budzącym powszechny niepokój, równocześnie towarzyszy mu entuzjastyczne przekonanie, iż społeczeństwo ma zdolność do rozwiązania tego problemu. Następnie szacowane są koszty rozwiązania problemu - jeśli są zbyt wysokie, następuje stopniowy spadek zainteresowania problemem. Kwestia ta przesuwana jest do porządku publicznego. W ostatnim etapie post-problem stage rozwiązanie problemu nie wchodzi w obszar działań rządu, nie wyklucza to jednak działań w obszarze pozarządowym, w którym mogą powstawać programy $\mathrm{w}$ celu radzenia sobie $\mathrm{z}$ daną kwestią ${ }^{10}$.

Problem społeczny to sytuacja, w której jakaś grupa społeczeństwa określa, że dana sytuacja jest niepożądana. Na problem rodziny składają się te warunki, które utrudniają życie rodzin; aby jednak te warunki zostały uznane za problem, ich opis i wyjaśnienie muszą zostać zaakceptowane przez sporą część populacji ${ }^{11}$. W tym kontekście uznanie małoletniego macierzyństwa w Polsce za problem społeczny czy też problem rodziny napotyka na trudność, ponieważ liczba małoletnich matek w Polsce nie jest znacząca. Dane demograficzne dotyczące urodzeń żywych przez małoletnie matki w latach 1970-2016 ukazują spadek liczby małoletnich matek: o ile w latach

rodzicielstwo jako zagrożenie bieda i wykluczeniem społecznym, Łódź 2010; zob. M. Jarosz, Zasoby adaptacyjne matek małoletnich, w: Skazani na wykluczenie!? Zasoby adaptacyjne osób zagrożonych marginalizacją społeczną, red. M. Kalinowski, I. Niewiadomska, Lublin 2010, s. 203-235.

10 A. Downs, za: J. W. Dearing, E. M. Rogers, Agenda-Setting, California 1996, s. 61.

11 S. L. Zimmerman, Family Policy. Constructed Solutions to Family Problems, California-London 2001, s. 33. 
70. XX wieku ich liczba wynosiła około siedmiu tysięcy rocznie, to w ostatnich latach obserwuje się spadek urodzeń, mniej więcej dotyczą one około trzech tysięcy małoletnich dziewcząt. Wśród małoletnich matek najliczniejszą grupę stanowią zwykle dziewczęta, które ukończyły siedemnaście lat ${ }^{12}$, kolejno sytuują się szesnastolatki ${ }^{13}$, natomiast najmniejszą grupę stanowią te dziewczęta, które urodziły przed ukończeniem piętnastego roku życia ${ }^{14}$. Zatem z wczesnym macierzyństwem corocznie musi się zmierzyć około trzech tysięcy rodzin, jednak $z$ uwagi na fakt, że państwo nie monitoruje sytuacji tych rodzin, nie jest możliwe określenie zakresu trudności, z jakimi borykają się te rodziny.

W literaturze przedmiotu, na podstawie nielicznych badań można wskazać, że macierzyństwo małoletniej córki stanowi dla rodziny nienormatywną sytuację wymagającą działań wspierających dziewczynę w nowych obowiązkach. Rodzina staje wobec decyzji dotyczących regulacji nowej prawnorodzinnej więzi obejmującej decyzje o formie opieki prawnej i pieczy nad dzieckiem córki, a także o alimentacji dziecka oraz uregulowaniu więzi prawnej między dzieckiem małoletniej a ojcem jej dziecka. Podjęcie tych decyzji uwarunkowane jest psychospołecznymi aspektami; zarówno małoletnia matka, jak i jej opiekunowie zmagają się z sytuacją kryzysową ${ }^{15}$.

W dyskursach społecznych kwestia małoletniego macierzyństwa jest ujawniana fragmentarycznie, podnoszone są kwestie o charakterze subiektywistycznym, czyli ukierunkowanym na rozwiązanie problemów małoletniego macierzyństwa w konkretnych społecznościach, takich jak szkoła ${ }^{16}$ czy też instytucje opiekuńcze i resocjalizacyjne ${ }^{17}$. W niektórych środowiskach macierzyństwo to uznawane jest za dewiację, czyli takie zachowanie, które przekracza normy społeczne i moralne, co w konsekwencji prowadzi

12 Główny Urząd Statystyczny, „Rocznik Demograficzny” 1970 - 5 122; 1990 - 5 580; 2000 - 4 003; 2010 - 2 883; 2016 - 1696.

13 Główny Urząd Statystyczny, „Rocznik Demograficzny” 1970 - 1392; 1990 - 1901 ; 2000 - 1 425; 2010 - 747; 2016 - 769.

14 Główny Urząd Statystyczny, „Rocznik Demograficzny” 1970 - 349; 1990 - 515; 2000 - 379; 2010 - 350; 2016 - 253.

15 Z. Izdebski, (Zbyt) młodzi dziadkowie, w: (Zbyt) młodzi rodzice, red. Z. Izdebski, T. Niemiec, K. Wąż, Warszawa 2011, s. 226-271.

16 Zob. U. Miernik, Małoletnie matki: obowiązek szkolny i obowiązek nauki, w: Eliminacja wykluczenia społecznego, red. M. Duda, K. Kutek-Sładek, Kraków 2016, s. 106-120.

17 Zob. R. Szczepanik, A. Sikora, Przedwczesne macierzyństwo w biografiach wychowanek placówek resocjalizacyjnych, w: Środowiskowy wymiar niedostosowania. Teorie - badania - praktyka, red. K. Sawicki, K. Konaszewski, Białystok 2014, s. 78-89. 
do stygmatyzacji małoletnich matek, a także ich dzieci. Definiowanie kwestii społecznej jako problemu społecznego uwarunkowane jest historycznie, bywa bowiem tak, że problemy są odkrywane ponownie i redefiniowane jako normalne zjawiska lub przynajmniej uznawane za niezagrażające ładowi społecznemu. Wczesne macierzyństwo zawsze było obecne w społeczeństwie polskim, jednak kryterium wieku przez długi czas nie miało takiego znaczenia społecznego jak sam fakt urodzenia pozamałżeńskiego ${ }^{18}$. Urodzenia pozamałżeńskie w Polsce stanowią obecnie większość urodzeń poniżej osiemnastego roku życia, nadal małoletnie matki doświadczają naznaczenia społecznego z powodu uznania ich zachowania za niemoralne ${ }^{19}$. Skala urodzeń pozamałżeńskich odsłoniła także nowy obszar trudności związanych z macierzyństwem małoletnich, które decydując się na samotne macierzyństwo, doświadczają odrzucenia przez rodziny pochodzenia, tracąc wsparcie ekonomiczne oraz pomoc w opiece nad dzieckiem. Wiele problemów społecznych współistnieje zatem z określonymi warunkami społecznymi i problemami, stanowi to kolejny istotny czynnik komplikujący rozumienie problemów społecznych ${ }^{20}$.

W literaturze podkreśla się także, iż w kreowaniu problemu społecznego dużą rolę odgrywa subiektywny składnik poczucia moralnego, decydujący o sposobie definiowania problemu społecznego. Co więcej, zauważa się, że członkowie klas społecznych mają tendencje do postrzegania rzeczywistości z punktu widzenia swojej klasy, tworząc zestaw definicji moralnych i stylu życia dla innych i siebie, które faktycznie są unikalne dla ich warstwy społecznej21. Frank F. Furstenberg, badający od wielu dekad zjawisko małoletniego macierzyństwa, zarzucił amerykańskim politykom uleganie złudzeniu, że biedni nastolatkowie zachowywaliby się tak samo jak ich rówieśnicy z klasy średniej, jeśli otrzymywaliby te same korzyści. System stratyfikacji społecznej przyczynia się do tego, że większa liczba osób dysponuje mniejszą ilością zasobów, w rezultacie osoby o niskich dochodach muszą podjąć większy wysiłek, aby uzyskać dostęp do zasobów społecznych. W przypad-

\footnotetext{
18 P. Szukalski, Płodność nastolatek w powojennej Polsce, „Wiadomości Statystyczne” (2009) nr 2, s. 32-45.

19 K. Ellis-Sloan, Teenage mothers, stigma and their 'presentations of self', „Sociological Research Online” 19 (1) 9. http://www.socresonline.org.uk/19/1/9.html (07.12.2018).

20 V. N. Parillo, Introduction, w: Encyclopedia of Social Problems, ed. V. N. Parillo, California 2008, s. 36.

21 V. N. Parillo, Introduction, dz. cyt...., s. 35.
} 
ku małoletnich matek celem polityki USA była poprawa jakości życia - miała ona zostać osiągnięta poprzez ograniczenie wczesnego macierzyństwa, dzięki czemu nastolatki mogłyby ukończyć szkołę, zdobyć doświadczenie zawodowe i znaleźć lepszych kandydatów na mężów. Działania te miały przyczynić się do ograniczenia liczby gospodarstw domowych prowadzonych przez samotne matki oraz zmniejszenia odsetka ubóstwa dzieci. Furstenberg zwrócił jednak uwagę, że ubóstwo małoletnich matek i ich dzieci jest czynnikiem przyczynowo-skutkowym w kształtowaniu ich życia, duże znaczenie mają jednak inne czynniki, takie jak słaba edukacja, niestabilność rodziny, pochodzenie, brak zaangażowania ojca w życie małoletniej, sytuacja zdrowotna małoletniej. Wczesna ciąża nie odgrywa tak znaczącej roli w tworzeniu się tej niekorzystnej sytuacji społecznej ${ }^{22}$.

Wobec powyższego próba określenia statusu problemu wobec małoletniego macierzyństwa powinna uwzględnić także współcześnie powstające polaryzacje w obszarze związanym z dobrobytem rodziny. Małoletnie matki w Polsce pochodzą ze zróżnicowanych środowisk rodzinnych, które stają się bądź nie źródłem zabezpieczenia społecznego. Jednak im niższej jakości były inwestycje rodzicielskie i społeczne w rozwój tych małoletnich, które stały się matkami, tym niższe stają się ich szanse życiowe po urodzeniu dziecka. Okazuje się, że osiągnięcia edukacyjne i zawodowe pozostają tak samo rozwarstwione jak w przeszłości. Szanse życiowe w dużym stopniu zależne są od kapitału kulturowego, społecznego i poznawczego, czyli dziedzictwa społecznego. O ile można określić liczbę małoletnich matek, które znalazły się w sytuacji, w której ich macierzyństwo wymagało instytucjonalnego wsparcia ${ }^{23}$, o tyle niemożliwe staje się zdiagnozowanie tych dziewcząt - matek i ich dzieci, które nie zostały z wielu względów uznane za wymagające wsparcia, mimo faktycznej potrzeby. Nierzadko więc dziewczęta te są zdane na poczucie moralne jednostek w środowisku lokalnym, które

22 F. Furstenberg, Destinies of the disadventeged. The politics of teenage childbearing, New York 2010, s. 161-164.

23 Pismo Rzecznika Praw Dziecka do Ministra Pracy i Polityki Społecznej w sprawie matek małoletnich przebywających w placówkach pieczy zastępczej, z dn. 25 października 2013 r., http://brpd.gov.pl/sites/default/files/rpd_stare/wystapienia/wyst_2013_10_25_ mpips.pdf (6.12.2018). W roku 2013 małoletnich w ciąży będących w pieczy zastępczej było 234, w tym 101 matek przebywało wraz z dziećmi w placówkach opiekuńczo-wychowawczych, według danych zebranych przez urzędy wojewódzkie 9 małoletnich matek przebywało $\mathrm{w}$ domach dla matek $\mathrm{z}$ dzieckiem oraz matek w ciąży. 
decydują o zakresie pomocy dla małoletniej matki i jej dziecka. Stanowi to niezbadaną kwestię społeczną.

Małoletnie macierzyństwo jest sytuacją wymagającą kompleksowego wsparcia państwa, dotyczy ono bowiem wyjątkowej sytuacji, w jakiej znajduje się rodzina. Zadaniem polityki rodzinnej jest konstruowanie rozwiązań problemów rodzinnych, zaś w ujęciu szerszym polityka ta zajmuje się ogólnym dobrostanem rodziny w państwie ${ }^{24}$. Polityka rodzinna obejmuje swym zakresem edukację życia rodzinnego, planowanie rodziny, opiekę nad dziećmi, adopcję, usługi opiekuńcze, ubezpieczenie społeczne, pomoc finansową, rozwój dziecka, opiekę ojcowską czy zastępcząa ${ }^{25}$, a także pomoc rodzinom niepełnosprawnym, wielodzietnym, pomoc w godzeniu obowiązków zawodowych i rodzinnych ${ }^{26}$. Polityka rodzinna według Adama Kurzynowskiego stanowi ogół norm prawnych, a także tych działań i środków, które są uruchamiane przez państwo celem stworzenia właściwych warunków dla jej powstawania, prawidłowego rozwoju, jak i wypełniania przez rodzinę społecznie istotnych funkcji. Polityka rodzinna ma na celu także tworzenie takich warunków życia, w których zaspokajane będą potrzeby młodego pokolenia: bytowe, kulturalne, edukacyjne i wychowawcze, gwarantujące równość szans życiowych ${ }^{27}$. Polityka rodzinna wobec małoletnich matek obejmuje przede wszystkim aspekt normatywny - oznacza to, że ustawodawca wprowadził przepisy umożliwiające stworzenie małoletnim matkom takich warunków, które będą wspierały ich rodzicielstwo.

Uważa się, że prawo odgrywa podstawową rolę w polityce rodzinnej. Przede wszystkim wskazuje i reguluje stosunki między członkami rodziny oraz między rodziną a społeczeństwem. Przepisy prawa określają także zasady udzielania wsparcia $\mathrm{z}$ tytułu świadczeń rodzinnych oraz innych instrumentów polityki. Znaczenie prawa w przypadku małoletniego macierzyństwa jest duże. Ustawodawca po raz pierwszy posłużył się pojęciem małoletniego rodzicielstwa w Rozporządzeniu Ministra Polityki Społecznej z dnia 8 marca 2005 r. w sprawie domów dla matek z małoletnimi dziećmi $\mathrm{i}$ kobiet $\mathrm{w}$ ciąży ${ }^{28}$. Kolejno $\mathrm{w}$ innych aktach wprowadzone zostało pojęcie

\footnotetext{
24 S. L. Zimmerman, Family Policy..., dz. cyt., s. 3-5.

25 S. L. Zimmerman, Family Policy..., dz. cyt., s. 3.

26 M. Szyszka, Polityka rodzinna w Polsce 1990-2004, Lublin 2008, s. 46.

27 A. Kurzynowski, Problemy rodziny w polityce społecznej, Warszawa 1991, s. 8.

28 Dz.U. Nr 43, poz. 418.
} 
małoletniej matki, małoletniej w ciąży ${ }^{29}$ lub małoletniej wychowującej dziec$\mathrm{ko}^{30}$. Małoletnia matka stała się podmiotem prawa, a pojęcie małoletniego macierzyństwa zostało wprowadzone w przestrzeń dyskursu społecznego.

Przez zastosowanie na poziomie językowym binarności odnośnie do pojęcia macierzyństwa w prawie polskim dokonano istotnego rozróżnienia między macierzyństwem kobiety pełnoletniej i niepełnoletniej. Niepełnoletnia matka jest definiowana przez pryzmat braku, czyli tego, kim nie jest - nie jest ona matką pełnoletnią wraz z atrybutem tej pełnoletniości, jakim jest władza rodzicielska nad swoim dzieckiem. Ten kontekst sprzyja przyjmowaniu strategii dyskursu - dotyczącego macierzyństwa małoletniego - ukierunkowanej na roszczenia wynikające z dyskryminacji ze względu na wiek czy też opresję skierowaną na małoletnie. Konsekwencją tego jest wysuwanie roszczeń o uprawnienia wynikające z faktu bycia matką. Szczególną uwagę zwraca się tutaj na macierzyństwo dziewcząt przebywających w różnego rodzaju placówkach opiekuńczych, ośrodkach wychowawczych oraz placówkach resocjalizacyjnych ${ }^{31}$.

$\mathrm{Na}$ poziomie normatywnym podstawowym odniesieniem dla polityki rodzinnej wobec macierzyństwa małoletniej jest art. 18 ustawy zasadniczej, który stanowi, że małżeństwo, rodzina, macierzyństwo i rodzicielstwo znajdują się pod szczególną ochroną i opieką Rzeczypospolitej Polskiej32. W doktrynie stwierdza się, że macierzyństwo jest wartością samoistną, czyli niezależną od stanu cywilnego matki, powinno być chronione bez względu na to, w jakiej sytuacji społecznej znajduje się matka i jej dziecko. Zwraca się także uwagę na tę szczególną relację między matką a jej dzieckiem, którą jest macierzyństwo, stąd też we wspomnianym art. 18 normodawca odróżnia macierzyństwo od rodzicielstwa. Macierzyństwo jest rozumiane jako związek matki z dzieckiem na płaszczyźnie biologicznej, emocjonalnej, społecznej i prawnej ${ }^{33}$. Uzupełnieniem tych norm są te wypływające

$29 \$ 18$ Rozporządzenie w sprawie instytucjonalnej pieczy zastępczej z dn. 22 grudnia 2011 r. Dz.U. Nr 292, poz. 1720.

$30 \$ 11.1$ a. ustawy z dn. 9 czerwca 2011 r. o wspieraniu rodziny i systemie pieczy zastępczej tekst jedn. Dz.U. 2017, poz. 697.

31 Sytuacja prawna, społeczna $i$ wychowawcza nieletnich ciężarnych i nieletnich matek przebywajacych $w$ placówkach resocjalizacyjnych, Raport z realizacji projektu „Chcę być z Tobą MAMO!", red. A. Sikora, Warszawa 2013.

32 Konstytucja Rzeczpospolitej Polskiej z dn. 2 kwietnia 1997 r., Dz.U. Nr 78, poz. 483 z późn. zm. i sprost.

33 M. Safjan, L. Bosek, Konstytucja RP. Tom I. Komentarz do art. 1-86, Warszawa 2016, s. 74. 
z art. 71 Konstytucji, które stanowią, że dobro rodziny i jej ochrona powinny być uwzględnione w polityce społeczno-gospodarczej, a szczególnej trosce podlegają rodziny wielodzietne, niepełne oraz matki przed urodzeniem dziecka i po nim. Normy te stanowią, iż macierzyństwo jest wartością chronioną niezależnie od wieku i stanu cywilnego matki.

\section{Status małoletniej matki w prawie}

Zmiana polityki wobec macierzyństwa małoletnich związana jest z głównym nurtem przemian życia rodzinnego i małżeńskiego. Zawarcie małżeństwa przez małoletnią ciężarną oraz małoletnią, która urodziła dziecko, stanowiło jedno z popularnych rozwiązań w ostatnich dekadach, współcześnie jest coraz rzadszym rozwiązaniem. Ustawodawca dopuszcza możliwość zawarcia małżeństwa przez małoletnią, jeśli ta ukończyła szesnaście lat oraz uzyskała zgodę sądu opiekuńczego. Art. $10 \$ 1$ kodeksu rodzinnego i opiekuńczego reguluje sytuację wczesnego małżeństwa, które bywa określane mianem małżeństwa naprawczego ${ }^{34}$. Przesłanką do zawarcia małżeństwa jest nie tylko wola stron, lecz także wystąpienie okoliczności zaistnienia ważnych powodów do zawarcia małżeństwa takich jak ciąża lub urodzenie dziecka przez małoletnią. Warunkiem koniecznym dla zgody sądu opiekuńczego jest dobro powstałej rodziny, której zadaniem jest stworzenie najkorzystniejszych warunków dla rozwoju dziecka małoletniej ${ }^{35}$. Według Zygmunta Radwańskiego małżeństwa takie zawierane są przede wszystkim ze względu na dobro dziecka, które urodziło się bądź ma się narodzić, a także po to, by młodym ludziom umożliwić życie w pełnowartościowej rodzinie ${ }^{36}$. W decyzjach sądów odnośnie do zgody na małżeństwo małoletniej ważną rolę odgrywa sytuacja wychowawcza matki, sytuacja prawno-rodzinna,

34 Małżeństwo „naprawcze” zawierano w celu zadośćuczynienia za szkody moralne ponoszone przez kobietę oraz jej rodzinę, a także ze względu na zalegalizowanie pochodzenie dziecka oraz zabezpieczenie utrzymania dziecka i jego matki. Zob. Z. Radwański, Komisja Nadzwyczajna do spraw zmian w kodyfikacjach /nr 55/ http://orka.sejm.gov.pl/Biuletyn. nsf/wgskrnr/NKK-55 (02.09.2018).

35 Ustawa z dn. 25 lutego 1964 r. Kodeks rodzinny i opiekuńczy, Dz.U. 2017, poz. 682, art. $10 \$ 1$.

36 Z. Radwański, Komisja Nadzwyczajna do spraw zmian w kodyfikacjach /nr 55/ http://orka.sejm.gov.pl/Biuletyn.nsf/0/59B3ACF3C3F2D3F0C1256EC2002DC6BA?OpenDocument (02.09.2018). 
a także okoliczności poczęcia dziecka. Sytuacja społeczno-prawna małoletniej, która zawarła małżeństwo za zgodą sądu, przez długi czas uznawana była za korzystniejszą od macierzyństwa realizowanego poza małżeństwem. Wczesne małżeństwa ulegały jednak szybkiej dezintegracji ${ }^{37}$. Polityka związana z wczesnym małżeństwem w zakresie regulowania sytuacji małoletniego macierzyństwa przez długi czas zabezpieczała stosunki prawno-rodzinne między matką małoletnią a jej dzieckiem. O ile małżeństwo małoletniej matki wiązało się z ryzykiem rozpadu rodziny, o tyle jednak dawało matce korzyść, której nie mogła wówczas uzyskać bez zawarcia związku małżeńskiego, czyli zmianę statusu prawnego małoletniości na pełnoletniość. Status pełnoletniej utrzymywała także w przypadku rozwodu ${ }^{38}$. Pełnoletniość zaś pozwalała matce na uzyskanie i sprawowanie władzy rodzicielskiej nad swoim dzieckiem.

\section{Zmiana polityki wobec małoletniego macierzyństwa}

Wraz z nowelizacją przepisów prawa rodzinnego w 2008 roku ${ }^{39}$ nastąpiła znacząca zmiana w regulacji stosunków rodzicielskich między małoletnią a jej dzieckiem. Ustawodawca stanowił w art. $96 \$ 2$ : „Rodzice, którzy nie mają pełnej zdolności do czynności prawnych, uczestniczą w sprawowaniu bieżącej pieczy nad osobą dziecka i w jego wychowaniu, chyba że sąd opiekuńczy ze względu na dobro dziecka postanowi inaczej”. Sprawowanie pieczy nad dzieckiem wiąże się przede wszystkim z podejmowaniem czynności dostosowanych do wieku dziecka, w przypadku małoletnich matek realizowanym poprzez czynności opiekuńczo-pielęgnacyjne. Doświadczenie pokazuje, że małoletnie matki są kompetentne do sprawowania pieczy

37 U. Kempińska, Małżeństwa młodocianych. Przyczyny i konsekwencje, Włocławek 2005, s. 118-119. Badania dotyczyły małżeństw zawartych w latach 1988-1999. Badania nad nietrwałością małżeństw prowadzili m.in. L. Mościcka, Diagnoza i prognoza trwałości matżeństw zawieranych za zgoda sądu: w świetle badań psychologicznych we Wrocławiu i w Krakowie w latach 1976-1980, Wrocław 1982; K. Marzec-Holka, Dezintegracja matżeństw zawartych za zgoda sądu, Bydgoszcz 1994.

38 Ustawa z dn. 23 kwietnia 1964 r. Kodeks cywilny, tekst jedn. Dz.U. 2017, poz. 459, art. $10 \$ 2$.

39 Ustawa z dn. 6 listopada 2008 r. o zmianie ustawy - Kodeks rodzinny i opiekuńczy oraz niektórych innych ustaw, Dz.U. 2008 Nr 220, poz. 1431. 
nad dzieckiem, o ile stworzone zostaną właściwe warunki dla wypełniania zadań wynikających z ich macierzyństwa.

Wprowadzone przepisy, jak się zauważa, odzwierciedlają faktyczną sytuację społeczną, a także wzmacniają więź prawną między matką a jej dzieckiem, takie zmiany postulowane były już w latach 90. XX wieku. Proponowano wówczas przyznanie władzy rodzicielskiej matce, która ukończyła szesnaście lat i która sprawowała pieczę nad dzieckiem, co pozwoliłoby zrównać sytuację w zakresie stosunków prawno-rodzinnych małoletniej samotnej $\mathrm{z}$ tą matką, która poprzez zamążpójście nabyła pełnoletniość ${ }^{40}$. Małoletnie matki wraz z decyzją o urodzeniu dziecka planują także związek małżeński z ojcem, jednak nie zawsze plany te udaje się zrealizować. Związki małoletnich mogą kończyć się wzajemnym rozczarowaniem oraz zawiedzeniem, jeszcze zanim urodzi się dziecko ${ }^{41}$. Prawo do sprawowania pieczy nad dzieckiem mają małoletnie realizujące swoje macierzyństwo w różnych sytuacjach opiekuńczo-wychowawczych ${ }^{42}$.

Należy oczywiście pamiętać, że małoletnia matka pozostaje pod władzą rodzicielską swoich rodziców. Urodzenie dziecka przez małoletnią córkę wprowadza nowy stosunek prawny do rodziny, wraz z określonymi uprawnieniami oraz obowiązkami. Przepisy prawa polskiego wskazują, iż „Rodzice i dzieci zobowiązani są do wzajemnego szacunku i wspierania się” (art. 87 k.r.o.). Warto odnieść się do tegoż przepisu, mając na uwadze rodzinę w sytuacji ciąży i urodzenia dziecka przez małoletnią córkę. Jak zauważa się w doktrynie: „Obowiązek szacunku oznacza powinność poszanowania szeroko pojętej integralności człowieka, ze szczególnym uwzględnieniem wzajemnej ochrony czci. Szacunek, nieprzypadkowo wymieniony w przepisie jako pierwszy, powinien cechować wszystkie wzajemne odniesienia rodziców i dziecka; stanowi on również wskazówkę przy realizacji obowiązku

40 T. Sokołowski, Władza rodzicielska nad dorastającym dzieckiem, Poznań 1987, s. 129.

41 A. Więcławska, Nieletnie dziewczęta samotnie wychowujące dzieci a ich przygotowanie do radzenia sobie z ograniczeniami losu. Diagnoza stanu kompetencji, Toruń 2005, s. 35.

42 Rozporządzenie Ministra Sprawiedliwości z dn. 17 października 2001 r. w sprawie zakładów poprawczych i schronisk dla nieletnich Dz.U. Nr 124, poz. 1359; Rozporządzenie Ministra Edukacji Narodowej z dn. 11 sierpnia 2017 r. w sprawie publicznych placówek oświatowo-wychowawczych, młodzieżowych ośrodków wychowawczych, młodzieżowych ośrodków socjoterapii, specjalnych ośrodków szkolno-wychowawczych, specjalnych ośrodków wychowawczych, ośrodków rewalidacyjno-wychowawczych oraz placówek zapewniających opiekę i wychowanie uczniom w okresie pobierania nauki poza miejscem stałego zamieszkania, Dz.U. 2017 poz. 1606. 
wzajemnego wspierania"43. Sytuacja ciąży i urodzenia dziecka wprowadza w zakres władzy rodzicielskiej nowe aspekty, takie jak alimentacja małoletniej, decyzje dotyczące nienarodzonego dziecka ${ }^{44}$, a także decyzje o sprawowaniu opieki prawnej nad dzieckiem małoletniej po jego urodzeniu. Bywa jednak, iż brak wiedzy rodziców dotyczący rozwiązań w zakresie stosunków prawnych oraz pomocy w przystosowaniu rodziny do nowej sytuacji może przyczyniać się do podejmowania decyzji unikających odpowiedzialności za córkę i jej dziecko, a małoletnie są umieszczane w ośrodkach opiekuńczych z powodu poczucia niekompetencji rodziców w nowej sytuacji. Umieszczenie w pieczy zastępczej, rodzinnej lub instytucjonalnej może zostać dokonane na podstawie orzeczenia sądowego, lecz może być także realizowane w przypadku pilnej konieczności na wniosek rodzica przeżywającego trudności opiekuńczo-wychowawcze ${ }^{45}$. Taką pilną sytuacją jest ciąża małoletniej przede wszystkim w sytuacji, w której trudne warunki bytowe zagrażają macierzyństwu małoletniej, możliwy jest także pobyt małoletniej w placówce po urodzeniu przez nią dziecka ${ }^{46}$. Ustawodawca dostrzega szczególnie trudną sytuację zagrożenia macierzyństwa małoletniej w domu rodzinnym spowodowaną brakiem akceptacji ciąży ze strony rodziców, a także w najbliższym środowisku. Z obawy o ryzyko działań, które mogłyby zmierzać do usunięcia ciąży, oraz o prawidłowy przebieg ciąży, zastosowano formę pomocy w postaci miejsca w bursach i internatach, w których ciężarne zamieszkają do porodu. Zgodnie z tą uchwałą uczennice w ciąży będą mogły zmienić szkołę w czasie roku szkolnego. Istotnym czynnikiem wskazanym $\mathrm{w}$ akcie jest troska o przyjazny klimat wobec małoletnich matek w szkołach i placówkach ${ }^{47}$.

Działania państwa w zakresie problemu małoletniego macierzyństwa są dostateczne, zazwyczaj jednak mają one charakter interwencyjny, czy-

43 A. Sylwestrzak, Art. 87, w: Kodeks rodzinny i opiekuńczy. Komentarz, red. H. Dolecki, T. Sokołowski, 2013, LEX 8820.

44 T. Sokołowski, Sytuacja prawna małoletniej matki przed urodzeniem dziecka, „Ruch Prawniczy Ekonomiczny i Socjologiczny" (1995) nr 2, s. 2.

45 Art. 35 u.w.r.p.z.

$46 \$ 18$ ust. 4 Rozporządzenia w sprawie instytucjonalnej pieczy zastępczej z dn. 22 grudnia 2011 r. Dz.U. Nr 292, poz. 1720. Ustawa z dn. 25 lipca 2014 r. o zmianie ustawy o wspieraniu rodziny i systemie pieczy zastępczej oraz niektórych innych ustaw, Dz.U. 2014, poz. 1188 , art. 95 ust 2.

47 Uchwała nr 160 Rady Ministrów z dnia 20 grudnia 2016 r. w sprawie programu kompleksowego wsparcia dla rodzin „Za życiem” M.P. 2016, poz. 1250. 
li są ukierunkowane na działania wspierające rodziny małoletnich matek w sytuacjach, gdy rodziny wykazują niewydolność w zakresie opieki nad małoletnią ciężarną lub po urodzeniu przez nią dziecka.

* $\quad * \quad *$

Dotychczasową politykę rodzinną wobec małoletnich matek oraz ich dzieci cechuje fragmentaryczność. Ustalenie ram prawnych małoletniego macierzyństwa można uznać za działanie inicjujące zmiany w postrzeganiu społecznym małoletnich matek i ich macierzyństwa. Ich status prawny wskazuje, iż są one uprawnione do realizowania macierzyństwa jako osoby małoletnie. Należy jednak stwierdzić, że działania państwa zostały ograniczone wyłącznie do ustalenia norm prawnych, które pokazują ogólne konteksty tego wczesnego macierzyństwa. Wydaje się, że konieczne jest wysunięcie postulatów o podjęcie dalszych kroków o charakterze diagnostycznym odnośnie do rodzinnej sytuacji macierzyństwa małoletnich matek, a w dalszej kolejności stworzenie poradnictwa specjalistycznego w celu wsparcia rodzin borykających się z sytuacją wczesnego macierzyństwa.

\section{Bibliografia}

Badinter E., Konflikt: kobieta i matka, przeł. J. Jedliński, Warszawa 2013.

Bunio-Mroczek P., Warzywoda-Kruszyńska W., Wczesne rodzicielstwo jako zagrożenie bieda i wykluczeniem społecznym, Łódź 2010.

Bunio-Mroczek P., Wczesne rodzicielstwo - zagrożenie czy szansa? Nastoletni rodzice $z$ łódzkich enklaw biedy, Łódź 2016.

Dearing J. W., Rogers E. M., Agenda-Setting, California 1996.

Ellis-Sloan K., Teenage mothers, stigma and their "presentations of self”, „Sociological Research Online"19 (1) 9, http://www.socresonline.org. $\mathrm{uk} / 19 / 1 / 9 . h t m l(07.12 .2018)$.

Furstenberg F., Destinies of the disadventeged. The politics of teenage childbearing, New York 2010.

Główny Urząd Statystyczny, „Rocznik Demograficzny” 2016. 
Izdebski Z., (Zbyt) młodzi dziadkowie, w: (Zbyt) młodzi rodzice, red. Z. Izdebski, T. Niemiec, K. Wąż, Warszawa 2011, s. 226-271.

Jarosz M., Zasoby adaptacyjne matek małoletnich, w: Skazani na wykluczenie!? Zasoby adaptacyjne osób zagrożonych marginalizacją społeczną, red. M. Kalinowski, I. Niewiadomska, Lublin 2010, s. 203-235.

Kempińska U., Małżeństwa młodocianych. Przyczyny i konsekwencje, Włocławek 2005.

Konstytucja Rzeczypospolitej Polskiej z dn. 2 kwietnia 1997 r., Dz.U. Nr 78, poz. 483 z późn. zm. i sprost.

Kurzynowski A., Problemy rodziny w polityce społecznej, Warszawa 1991.

Marzec-Holka K., Dezintegracja małżeństw zawartych za zgodą sądu, Bydgoszcz 1994.

Miernik U., Małoletnie matki: obowiązek szkolny i obowiązek nauki, w: Eliminacja wykluczenia społecznego, red. M. Duda, K. Kutek-Sładek, Kraków 2016, s. 106-120.

Mikołajczyk-Lerman G., Małoletnie rodzicielstwo jako problem psychospołeczny, „Polityka Społeczna” 8 (2007), s. 54-59.

Mościcka L., Diagnoza i prognoza trwałości małżeństw zawieranych za zgodą sądu: w świetle badań psychologicznych we Wrocławiu i w Krakowie w latach 1976-1980, Wrocław 1982.

Padała O. i in., Młodociane macierzyństwo jako problem społeczny i medycz$n y$, „European Journal of Medical Technologies” 2 (2014) nr 3, s. 61-65.

Parillo V.N., Introduction, w: Encyclopedia of Social Problems, ed. V.N. Parillo, California 2008, s. 35-38.

Pismo Rzecznika Praw Dziecka do Ministra Pracy i Polityki Społecznej w sprawie matek małoletnich przebywających w placówkach pieczy zastępczej, z dn. 25 października 2013 r., http://brpd.gov.pl/sites/default/ files/rpd_stare/wystapienia/wyst_2013_10_25_mpips.pdf (6.12.2018).

Radwański Z., Komisja Nadzwyczajna do spraw zmian w kodyfikacjach /nr 55/http://orka.sejm.gov.pl/Biuletyn.nsf/wgskrnr/NKK-55 (02.09.2018).

Rozporządzenie w sprawie instytucjonalnej pieczy zastępczej z dn. 22 grudnia 2011 r. Dz.U. Nr 292, poz. 1720.

Rozporządzenie Ministra Edukacji Narodowej z dn. 11 sierpnia 2017 r. w sprawie publicznych placówek oświatowo-wychowawczych, młodzieżowych ośrodków wychowawczych, młodzieżowych ośrodków socjoterapii, specjalnych ośrodków szkolno-wychowawczych, specjalnych ośrodków wychowawczych, ośrodków rewalidacyjno-wychowawczych 
oraz placówek zapewniających opiekę i wychowanie uczniom w okresie pobierania nauki poza miejscem stałego zamieszkania, Dz.U. 2017 poz. 1606.

Rozporządzenie Ministra Sprawiedliwości z dn. 17 października 2001 r. w sprawie zakładów poprawczych i schronisk dla nieletnich Dz.U. $\mathrm{Nr}$ 124, poz. 1359.

Safjan M., Bosek L., Konstytucja RP. Tom I. Komentarz do art. 1-86, Warszawa 2016.

Sikorska M., Matka „chora” zamiast „złej” - o nowych wzorach macierzyństwa, w: Być rodzicem we współczesnej Polsce. Nowe wzory w konfrontacji z rzeczywistościa, red. M. Sikorska, Warszawa 2009, s. 13-33.

Sokołowski T., Sytuacja prawna małoletniej matki przed urodzeniem dziecka, „Ruch Prawniczy Ekonomiczny i Socjologiczny” (1995) nr 2, s. 1-9.

Sokołowski T., Władza rodzicielska nad dorastajacym dzieckiem, Poznań 1987.

Sylwestrzak A., Art. 87, w: Kodeks rodzinny i opiekuńczy. Komentarz, red. H. Dolecki, T. Sokołowski, 2013, LEX 8820.

Sytuacja prawna, społeczna $i$ wychowawcza nieletnich ciężarnych i nieletnich matek przebywajacych $w$ placówkach resocjalizacyjnych. Raport $\mathrm{z}$ realizacji projektu „Chcę być z Tobą, MAMO!”, red. A. Sikora, Warszawa 2013.

Szczepanik R., Sikora A., Przedwczesne macierzyństwo w biografiach wychowanek placówek resocjalizacyjnych, w: Środowiskowy wymiar niedostosowania. Teorie - badania - praktyka, red. K. Sawicki, K. Konaszewski, Białystok 2014, s. 78-89.

Szukalski P., Płodność nastolatek w powojennej Polsce, „Wiadomości Statystyczne" (2009) nr 2, s. 32-45.

Szyszka M., Polityka rodzinna w Polsce 1990-2004, Lublin 2008.

Uchwała nr 160 Rady Ministrów z dn. 20 grudnia 2016 r. w sprawie programu kompleksowego wsparcia dla rodzin „Za życiem” M.P. 2016, poz. 1250.

Ustawa z dn. 23 kwietnia 1964 r. Kodeks cywilny, tekst jedn. Dz.U. 2017, poz. 459.

Ustawa z dn. 25 lipca 2014 r. o zmianie ustawy o wspieraniu rodziny i systemie pieczy zastępczej oraz niektórych innych ustaw, Dz.U. 2014, poz. 1188 . 
Ustawa z dn. 25 lutego 1964 r. Kodeks rodzinny i opiekuńczy Dz.U. 2017, poz. 682.

Ustawa z dn. 6 listopada 2008 r. o zmianie ustawy - Kodeks rodzinny i opiekuńczy oraz niektórych innych ustaw Dz.U. 2008 Nr 220, poz. 1431.

Ustawa z dn. 6 stycznia 2000 r. o Rzeczniku Praw Dziecka, tekst jedn. Dz.U. Nr 6, poz. 69.

Ustawa z dn. 9 czerwca 2011 r. o wspieraniu rodziny i systemie pieczy zastępczej, tekst jedn. Dz.U. 2017, poz. 697.

Warzywoda-Kruszyńska W., Dzieciocentryczna polityka społeczna w założeniach i praktyce, w: O racjonalna politykę rodzinna. Rodzina formacja niezastapioną, red. M. Bednarski, Z. Czepulis-Rutkowska, D. Głogosz, Warszawa 2017, s. 45-54.

Więcławska A., Nieletnie dziewczęta samotnie wychowujące dzieci a ich przygotowanie do radzenia sobie z ograniczeniami losu. Diagnoza stanu kompetencji, Toruń 2005.

Włodarczyk E., Nastoletnie macierzyństwo jako problem indywidualny i społeczny, w: Kapitał społeczny a nierówności - kumulacja i redystrybucja, red. K. Marzec-Holka, Bydgoszcz 2009, s. 454-463.

Zimmerman S. L., Family Policy. Constructed Solutions to Family Problems, California-London 2001. 